\title{
Development Process Patterns for Distributed Onshore/Offshore Software Projects
}

\author{
Ravinder Singh \\ AVP, JP Morgan Chase \& Co \\ Research Scholar, \\ Department of Informatics, \\ King's College, London, UK
}

\author{
Dr. Kevin Lano \\ Reader \\ Department of Informatics, \\ King's College, London, UK
}

\begin{abstract}
- the globalisation of the commercial world, and the use of distributed working practices (Offshore/ onshore/ nearshore) has increased dramatically with the improvement of information and communication technologies. Many organisations, especially those that operate within knowledge intensive industries, have turned to distributed work arrangements to facilitate information exchange and provide competitive advantage in terms of cost and quicker delivery of the solutions. The information and communication technologies (ICT) must be able to provide services similar to face-to-face conditions. Additional organisations functions must be enhanced to overcome the shortcomings of ICT and also to compensate for time gaps, cultural differences, and distributed team work. Our proposed model identifies four key work models or patterns that affect the operation of distributed work arrangements, and we also propose guidelines for managing distributed work efficiently and effectively.
\end{abstract}

Keywords-Distributed work; Onshore; Offshore; Software; IT projects; Programme and project Management

\section{INTRODUCTION}

People and organisations have been communicating and managing work over long-distances and multiple countries since ancient times also. Earlier, such distributed work and exchange of information was achieved by the physical travel of people, which made the flow of information slow and coordinating the work tedious and also costly.

Distributed environment of projects in the present multinational organisations gives rise to more complexities in all areas of project management. Therefore standard project management methodologies have to be enhanced to meet diverse requirements from various stakeholders. The studies showed that distributed work environment has its own challenges and advantages. The challenges could be such as managing different time zones, cultural differences, virtual communication environments and costs associated with them, and many more. The advantages could be in terms of providing good quality projects at lower cost. This requires proper documentations, setup the correct expectations, managing various stakeholders and also managing the cross cultural issues effectively and efficiently. The conflict resolution criterion and transparent communication is the key to success in global scenarios and managing successful projects.
Previous research had been focusing on different aspects of the program and project management such as study of models and framework, empirical, and statistical studies. The studies had been conducted in different industry sectors but most of the research has been in the software and IT industry as given in the following table.

Varied results from the work put organisations in difficult situations for the standardisations of processes to implement distributed work environments. Previous researchers have implied that this may be due to the lack of well-established framework for distributed work environments. One of the solutions could be to use the standard organisational theories to overcome the problems of distributed work environments. Even these theories are not sufficient to address the issues of the distributed work environment.

This paper proposes a new set of frameworks and identifies five models for using the distributed work more efficiently and effectively. The work highlights the use of various models and the conditions for its use. This work also put forwards different guidelines for helping to complete the distributed work in a more organised manner. These models are then applied to two organisations to see their impact on the overall performance of teams.

This paper introduces the various models available for distributing work between a customer site and the delivery/development centre (DC) network. These models are applicable for moving work to onshore/ offshore/ near-shore DCs. However, moving work offshore introduces additional risks that are explained in more detail in Risk Management Guidelines for Distributed Work.

\section{DISTRIBUTED WORK APPROACHES}

The details about the four model (customer-centric, DCcentric, multi-centre and tailored) is explained below along with a brief overview and the main characteristics of each. Various work models, when to use a particular model and application of each model is also discussed. 


\begin{tabular}{|c|c|c|c|}
\hline $\begin{array}{l}\text { Ref. } \\
\text { No. }\end{array}$ & $\begin{array}{l}\text { Category/ } \\
\text { Topic }\end{array}$ & Study Description/ Method/ Argument/ Theoretical Approach & Results, gaps, and Conclusions \\
\hline & \multirow{13}{*}{$\begin{array}{l}\text { Project } \\
\text { Manageme } \\
\text { nt in Global } \\
\text { Distributed } \\
\text { Environme } \\
\text { nt }\end{array}$} & \multicolumn{2}{|c|}{$\begin{array}{l}\text { Managing projects in global distributed has its own challenges [1-24]. Researchers had explored use of different methodologies, } \\
\text { techniques, tools for managing distributed projects from standard processes to incentive based approaches. }\end{array}$} \\
\hline 1. & & $\begin{array}{l}\text { With the exponential growth of communication technologies and } \\
\text { information systems, the globalisation of the commercial world has also } \\
\text { increased significantly. }\end{array}$ & $\begin{array}{l}\text { This research paper highlighted that in order to } \\
\text { increase efficiency, productivity, quality and cost } \\
\text { effectiveness, organisations are going for outsourcing } \\
\text { and distributing their wok globally. }\end{array}$ \\
\hline 2. & & $\begin{array}{l}\text { This research study described the importance of software requirement } \\
\text { specification (SRS) document to the success of global software projects. } \\
\text { The authors discussed various difficulties in creating a standard SRS as } \\
\text { companies have their own methods of creating such documents. }\end{array}$ & $\begin{array}{l}\text { The authors studied how Capgemini overcame the } \\
\text { issue of creating standard SRS by using specification } \\
\text { patterns so as to create synergy among the global } \\
\text { teams. }\end{array}$ \\
\hline 3. & & $\begin{array}{l}\text { The significance of knowledge sharing among global teams and } \\
\text { stakeholders and how it can be addressed by mature processes and tools } \\
\text { is highlighted in this study. There will be lesser readjustment required if } \\
\text { the processes, methods and tools are used enterprise wide. }\end{array}$ & $\begin{array}{l}\text { The authors proposed that enterprise wide software } \\
\text { should be used for project assurance, quality and } \\
\text { knowledge sharing. } \\
\text { The software would help provide timely information, } \\
\text { data and visibility for the preventive and corrective } \\
\text { actions to be taken for better execution of the project. }\end{array}$ \\
\hline 4. & & $\begin{array}{l}\text { This study described the team structure for successful completion of } \\
\text { offshore projects. The authors studied two types of structures for offshore } \\
\text { teams and highlighted the problems faced by managers for changing the } \\
\text { team structure and organisation model. }\end{array}$ & $\begin{array}{l}\text { The paper proposed that changes have to be done to } \\
\text { the existing structure for successful global operations. } \\
\text { The team structures for managing offshore teams for } \\
\text { various phases of the project and the reporting } \\
\text { structure has to be managed keeping tin to account } \\
\text { various time zone issues, cultural issues and skills } \\
\text { availability. }\end{array}$ \\
\hline 5. & & $\begin{array}{l}\text { A framework for managing risks in global software projects is proposed } \\
\text { in this research paper. The integrated framework had been created for } \\
\text { distributed projects based on various parameters and requirements of } \\
\text { global environment. }\end{array}$ & $\begin{array}{l}\text { The framework proposed the use of various } \\
\text { communication channels, different set of development } \\
\text { environment for different needs/ requirements of the } \\
\text { stakeholders and projects. The flow chart could also } \\
\text { help to provide better information across the } \\
\text { organisation. }\end{array}$ \\
\hline 6. & & $\begin{array}{l}\text { This research studied the impact of communication media like email, } \\
\text { messaging, phone etc. on the conflict resolution in global teams. The } \\
\text { authors tried to evaluate which could be the best sequence or combination } \\
\text { of media tools for communication for resolving the conflicts. }\end{array}$ & $\begin{array}{l}\text { The study showed how the cross cultural issues, } \\
\text { different communication channels, time zone } \\
\text { management had to be taken into account for } \\
\text { managing global teams/ people effectively. } \\
\text { The process for conflict management has to be robust } \\
\text { and transparent so that the conflicts can be controlled/ } \\
\text { resolved in an efficient manner. }\end{array}$ \\
\hline 7.. & & $\begin{array}{l}\text { In this study, authors tried to analyse the global development projects } \\
\text { using framework so as to overcome various issues in the distributed } \\
\text { projects. The authors tried to study the processes used by various } \\
\text { organisations to manage the distributed projects efficiently and } \\
\text { effectively, and maximise the benefits of onshore-offshore delivery. }\end{array}$ & $\begin{array}{l}\text { The paper showed different models and frameworks } \\
\text { used by global organisations to manage the distributed } \\
\text { projects successfully. Various activities can be } \\
\text { distributed offshore/ near-shore or onshore and also } \\
\text { the life cycle divided among them for maximising the } \\
\text { benefits. }\end{array}$ \\
\hline $8 .$. & & $\begin{array}{l}\text { This research studied different communicating media and its application } \\
\text { the global agile software development projects. }\end{array}$ & $\begin{array}{l}\text { The authors found that instant messaging is a good } \\
\text { substitute tool for face to face communication and } \\
\text { email is good tool for wider and enterprise wide } \\
\text { information sharing. }\end{array}$ \\
\hline 9. & & $\begin{array}{l}\text { This research paper proposed predicting the outcome of global software } \\
\text { development projects with the application of analytical modelling. The } \\
\text { analytical models are parameterised to accommodate the single-site or } \\
\text { multi-sites, team sizes, skills levels, expertise, availability, and support } \\
\text { level etc. }\end{array}$ & $\begin{array}{l}\text { The paper suggested various types of models for } \\
\text { distributing various phases/ stages between offshore } \\
\text { and onshore sites. }\end{array}$ \\
\hline 10. & & $\begin{array}{l}\text { This research study described the processes for managing a multi-site } \\
\text { software development project is complex and requires a very good } \\
\text { collaboration among teams. }\end{array}$ & $\begin{array}{l}\text { The study suggested management of multi-site projects } \\
\text { can be improved using networked virtual environment } \\
\text { which allows for better communication, familiarity, } \\
\text { sharing, mentoring, faith and faster resolution of } \\
\text { conflicts. }\end{array}$ \\
\hline 11. & & $\begin{array}{l}\text { This research studied the growth of teams in distributed software } \\
\text { development projects. The authors had tried to study the growth of teams } \\
\text { in terms of expertise, communication skills, economic impact and } \\
\text { working conditions. }\end{array}$ & $\begin{array}{l}\text { The study described the communication channels, } \\
\text { skills and the impact of virtual communication } \\
\text { techniques for successful management of teams and } \\
\text { projects in global environment. } \\
\text { The better the economic and working condition, the } \\
\text { better would be the team morale and more successful } \\
\text { project management. }\end{array}$ \\
\hline 12. & & This research paper explained that the "Distributed Work" is basically a & The research highlighted the importance of \\
\hline
\end{tabular}




\begin{tabular}{|c|c|c|}
\hline & $\begin{array}{l}\text { number of different work provisions. Since the teams are distributed } \\
\text { globally, and are separated by time zones, the managers have to rely } \\
\text { heavily on the availability and efficiency of communications tools and } \\
\text { information systems. }\end{array}$ & $\begin{array}{l}\text { communication tools and information systems for } \\
\text { successful management of global teams and projects. }\end{array}$ \\
\hline 13. & $\begin{array}{l}\text { Use of incentive based theories to the distributed work environments is } \\
\text { described in this research paper. The paper endeavours to address two } \\
\text { subjects; firstly, to understand the effect of incentives on the worker's } \\
\text { choice for using distributed work environment, and secondly the } \\
\text { collaboration of multiple incentives or disincentives across organisation, } \\
\text { groups or individuals. This paper also looks into motives as to why } \\
\text { people always prefer to take up distributed work environment. The } \\
\text { theory of incentive is applied to two organisations to understand the } \\
\text { behaviour and pattern. }\end{array}$ & $\begin{array}{l}\text { The research suggested that people prefer distributed } \\
\text { work environment because of flexibility, incentives, } \\
\text { and availability. The disincentives are managing } \\
\text { different time zones and culture. } \\
\text { The study showed that incentives highly influence the } \\
\text { working of people and opting for distributed working. } \\
\text { It also highlighted that work life balance is one of the } \\
\text { main criterion for people for remote/ home working. }\end{array}$ \\
\hline 14. & $\begin{array}{l}\text { This research paper studied as why organisations choose for distributed } \\
\text { work environment. The research was conducted to understand the use of } \\
\text { distributed work environments in terms of costs, efficiency and } \\
\text { productivity, motivation of employees, and impact on the group's } \\
\text { outputs. }\end{array}$ & $\begin{array}{l}\text { The research suggested that the use of distributed work } \\
\text { environments is to mainly reduce the costs, improve } \\
\text { efficiency and productivity, motivate employees, and } \\
\text { impacting the group outputs positively. }\end{array}$ \\
\hline $\begin{array}{l}15- \\
18\end{array}$ & $\begin{array}{l}\text { Even though there is clear impact on the employees for the work-life } \\
\text { balance, more flexibility but there are conflicting observations made } \\
\text { which are owing to more distractions at home which results in increased } \\
\text { stress. }\end{array}$ & $\begin{array}{l}\text { These papers showed that remote working, home } \\
\text { working or flexible working is able to provide better } \\
\text { work life balance but at the same time needs more } \\
\text { planning as it could also lead to more distractions at } \\
\text { home and less work. The employees have to manage } \\
\text { themselves more efficiently to be more productive. } \\
\text { Organisations provide hot-desk facilities to save on } \\
\text { cost of space and also improve its travel carbon } \\
\text { footprint. }\end{array}$ \\
\hline 19. & $\begin{array}{l}\text { This research paper defined knowledge intensive firms as those that } \\
\text { "offer to the market the use of fairly sophisticated knowledge or } \\
\text { knowledge-based products". Knowledge intensive firms can be divided } \\
\text { into professional service, and research \& development firms such as } \\
\text { engineering and law firms or pharmaceutical companies. Knowledge } \\
\text { intensive firms differ from other types of organisations through the } \\
\text { organisation's massive reliance on the intellectual skills of its employees } \\
\text { to carry out its core functions. }\end{array}$ & $\begin{array}{l}\text { Although many of the problems and barriers to } \\
\text { distributed work are not unique to knowledge intensive } \\
\text { firms, the sophisticated nature of the knowledge these } \\
\text { firms typically deal in has the potential to magnify } \\
\text { these problems. } \\
\text { This report focuses on the interaction of individuals } \\
\text { and teams within knowledge intensive firms and the } \\
\text { ways that they interact and perform under distributed } \\
\text { work arrangements. }\end{array}$ \\
\hline 20. & $\begin{array}{l}\text { This research defined a virtual team as "groups of people employed in a } \\
\text { shared task while geographically separated and reliant on electronic } \\
\text { forms of communication". }\end{array}$ & $\begin{array}{l}\text { The research paper compared various factors such as } \\
\text { telephonic conferences, video conferences, e-mails, } \\
\text { time zones, and for managing virtual teams. } \\
\text { The virtual communication tools are important and } \\
\text { also people should be sensitive to the cultural } \\
\text { communication styles and language used in } \\
\text { communication to overcome misunderstandings and } \\
\text { reduce communication gap. }\end{array}$ \\
\hline 21. & $\begin{array}{l}\text { The paper defines the term remote resourcing as "carrying out work in an } \\
\text { office remote from the point where a project is principally delivered". } \\
\text { The report defines remote resourcing when virtual communication tools } \\
\text { are used and teams are distributed at one or more sites in different } \\
\text { geographical locations. }\end{array}$ & $\begin{array}{l}\text { These terms essentially describe interactions between } \\
\text { people separated by physical distance who perform } \\
\text { most of their work through communication } \\
\text { technology. Within the body of this report the term } \\
\text { distributed work is used to represent this concept. The } \\
\text { dynamic changes to the project are handled more } \\
\text { effectively when the team is at one place and long- } \\
\text { term projects can get greater benefits from remote } \\
\text { teams or by distributed working. }\end{array}$ \\
\hline 22. & $\begin{array}{l}\text { The research paper discusses that distributed work covers many } \\
\text { alternative methods of work which include satellite offices, flexible work } \\
\text { arrangements, telecommuting and global collaborative teams. }\end{array}$ & $\begin{array}{l}\text { The paper describes that distributed work could be } \\
\text { defined in many different ways. The distributed teams } \\
\text { could use different ways of working from flexible } \\
\text { home working to offshore, onshore or near-shore } \\
\text { arrangements. The paper highlighted that distributed } \\
\text { teams and working are often used to reduce overall } \\
\text { cost and improve services. }\end{array}$ \\
\hline 23. & $\begin{array}{l}\text { This paper describes various issues and problems faced by distributed } \\
\text { work faces which are similar to all the issues and problems that normal } \\
\text { collocated group's face, with the added complexity of workers being } \\
\text { based at locations remote from each other, be it in the next room or in } \\
\text { another country The inclusion of IT as a required element of many } \\
\text { definitions reflects the importance of ICT as a replacement media to } \\
\text { mimic the communicative and collaborative qualities inherent in } \\
\text { collocated work groups. }\end{array}$ & $\begin{array}{l}\text { This paper highlighted that distributed work faces } \\
\text { many more problems in addition to the normal projects } \\
\text { at one site. The projects and teams distributed in } \\
\text { different locations brings in the importance of good } \\
\text { communication media and skills, cross cultural issues } \\
\text { and management, time zone management, and clear } \\
\text { understanding of the stakeholders' expectations. } \\
\text { The project documentation has to be detailed and }\end{array}$ \\
\hline
\end{tabular}




\begin{tabular}{|l|l|l|l|}
\hline \multirow{2}{*}{24.} & & $\begin{array}{l}\text { shared with all teams highlighting various milestones } \\
\text { and deliverables and also giving details of } \\
\text { communication requirements. }\end{array}$ \\
\cline { 3 - 4 } & & $\begin{array}{l}\text { This research explained that small and medium enterprises (SMEs) are } \\
\text { also facing huge competition due to globalisation of economies and } \\
\text { easier availability of cheaper and good quality products, services across } \\
\text { the world. }\end{array}$ & $\begin{array}{l}\text { This paper highlighted that in order to stay ahead of } \\
\text { the competition and technology SMEs should focus on } \\
\text { to e-collaborations through project management } \\
\text { approach. This will ensure them structured processes, } \\
\text { better visibility for managing the full life cycle of the } \\
\text { project and giving them better monitoring and control } \\
\text { of project execution. }\end{array}$ \\
\hline
\end{tabular}

\section{Customer-Centric Model}

With the use of this model the majority of the work is completed at the customer site, and the detailed design, build, and component tests are done at the delivery/development centre.

The customer team transfers the well codified tasks to the delivery centre to be executed with the most discipline and rigor. This distribution model can be used for both onshore and offshore delivery centres and may have to be adapted to suit specific constraints of the project and stakeholders.

Main characteristics of the Customer-centric model are as follows:

- The most basic model, suitable for first time users

- Moderate cost savings

- Moderate risk

- Suitable for all project sizes

- Limits cost savings because only a small portion of the life cycle is completed at the delivery centre

- May not be suitable for development of components that involve a high degree of communication with the customer (e.g., UI, data manipulations, etc.)

- May not be suitable for development of new/complex applications

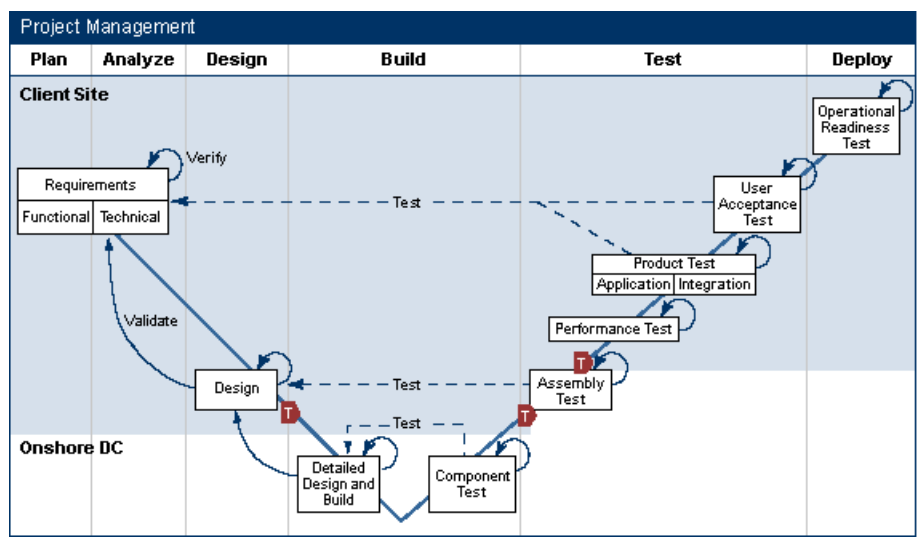

Fig. 1. Customer-centric Distribution Model

This model represents a minimum amount of risk from the long-distance cross-site communication. The physical distance has less of an effect on communication than significant time zone differences, but Time zone differences can prevent project team members from communicating with each other in real time. Even though this is the most basic distribution work environment, it may still be a perfect model to execute "forever" depending on the stakeholder expectations.

\section{Benefits}

- Simple, stable, and repetitive processes. Only a small portion of the development life cycle is executed at the delivery centre. Transition points control the interaction between customer and the delivery centre sites. Also, formal and informal communication ensures a proper flow of information.

- Robust and scalable. The process' simple design gives the delivery centre site these characteristics. This will achieve cost-savings.

- Minimal communication. The delivery centre site's communication is between the design and build teams and rarely involves the customer. The low amount of communication is because of the formal and specific design deliverables that are less open to interpretation than requirements.

- Works well with offshore centres. Due to all previously listed characteristics (repeatability, scalability, and robustness); this distribution model works well with offshore centres.

Cross-site liaisons ensure a smooth issue resolution process.

\section{Drawbacks}

- Since this model limits the types of tasks which can be done at delivery/ development centres, therefore costsavings which can be realised are also limited.

- Assembly tests may not be fully conducted at delivery/development centre when an application comprises cross-platform assemblies of components and these components are developed using separate toolsets.

\section{Applications}

- This model is particularly desirable for custom-based or packaged solutions that require a pool of skilled programmers producing large-scale applications.

- When planning to work with an offshore centre, use a nearby onshore centre as an intermediary as this will save time and effort during project planning and the project execution phases. Onshore centres should have 
more application analysis and business skills than their offshore counterparts.

- Impact of required levels of communication.

- Since this model uses minimum communication with the customer, therefore it may not be suitable to developing the application components that require a high degree of communication with the customer (e.g., UI components, reports, integration etc.).

- This model may not be suitable for developing application components that fit into a new application architecture, as it may require a high-level of communication with the design team. This can be mitigated by having the technical architecture development team at the delivery centre. For developing a new architecture, completing it as "Release 0 " at the customer site will reduce the risk.

- Transition of the application back to the onshore team and whether this occurs before or after assembly test (indicated by the red transition points) needs to be carefully considered. Transition prior to assembly test means a change in team and ownership, but may be required due to technical testing constraints (e.g., crossplatform environments) or contractual obligations (e.g., only delivering one part of the application). However, where possible, execution of assembly test is more effectively performed by the development team prior to any significant handover or transition to another organization (e.g., the formal onshore test team).

There are circumstances where even the most basic distribution models cannot be executed and require all tasks to execute at the customer sites. For instance, if the customer is uncomfortable or unwilling to see part of the effort executed at a delivery/development centre or has a particular environment, the delivery centre personnel can work at the customer site.

\section{DC-CENTRIC MODEL}

In this model, most of the work is done at the delivery/development centre. The customer site completes only requirements gathering/analysis and user acceptance testing. DC-centric model characteristics include the following:

- Moderate cost savings when applied with an onshore centre

- Significant cost savings when applied with an offshore centre

- Low risks when applied with a onshore centre

- Increased risk with the distance and time zone differences between the customer and delivery centre sites

- Suitable for a wide variety of applications

- Suitable for use with all project sizes

- Requires a higher maturity DC and team experienced with multi-site projects to execute

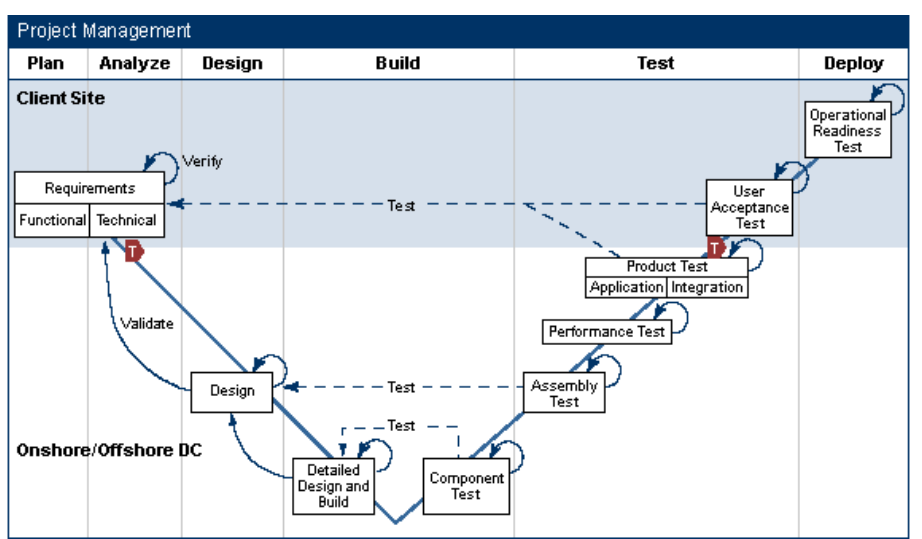

Fig. 2. DC-centric Distribution Model

DC-centric distribution model enables significant costsavings at low-to-moderate risk levels because of the task distribution. This is the predominant distribution model used for custom development by the onshore/offshore/near-shore centres today may have to be customised to the suit specific constraints of the project and stakeholders.

This model can be used only when the customer team is experienced in delivering projects with offshore centres, and the offshore centre is relatively mature (e.g. CMMI Level-2 or higher, Six sigma, etc.) and has demonstrated expertise in the project management, technologies and applications. In order to reduce risk, start the project with a more basic approach, i.e., the Customer-centric Distribution model, and then progressively migrate additional activities offshore. The desired end-state is best achievable over a period of time.

\section{Characteristics}

- This model requires higher levels of communication between the sites than the Customer-centric Distribution model. The key transition point between the sites in this distribution model lies between analysis and design, while in the Customer-centric model focuses between design and detailed design:

- In a typical situation, Transition Point Overview results in a higher level of communication between the sites because it may involve communication and resolution of issues with the customer and the set-up is less tolerant to delays caused by distance and time zone separation.

- Application design deliverables are easier to specify than application requirements Transition Point Overview to a sufficient level of detail and without (or with less) ambiguity. This makes the application design deliverables less prone to misinterpretation. Detailed standards exist for specifying the design, while requirements are typically defined more generally and are open to broad interpretation.

- Since this model requires higher levels of communication, it will work well with delivery centres in close time zone proximity to the customer sites. Significant time zone differences will make it difficult for team members to communicate synchronously. 
- Engagements based on established offerings and/or assets are particularly well suited to this model, since there are fewer risks related to miscommunication when using stable technologies, environments, and processes.

- This may be the predominant model for working with onshore centres.

\section{Benefits}

- This model will enable the realization of maximum cost-savings, as most development tasks are completed at the delivery/ development centre with a more costefficient workforce, standard repeatable processes, application-specific methodologies and job aids, reusable assets, etc.

- Since this model was previously used at onshore centres, significant processes, experts, and procedures can be used for the effective management.

\section{Drawbacks}

- The distance and time zone differences between the customer and delivery/development centres increases risk.

- This model requires mature (e.g. CMMI, Six Sigma, ISO etc.) and experienced offshore centres to work successfully.

\section{Applications}

- Address the risks through various risk mitigation strategies when applying this distribution model with offshore centres:

- To reduce the communication gap and reduce the rework activities, investment is required communication infrastructure (e.g., internet connectivity, configuration management tools, video conferencing, etc.).

- Customer can build and invest in the communication technologies at site only if the project is long-term to recover the cost. Otherwise customer can use third party service providers to meet short term goals.

- An onshore or near-shore centre as an intermediary may be used when using an offshore centre to reduce start-up costs and to reduce the issues related to offshore development.

\section{TAILORED MODEL}

With the maturity of customer team and offshore centre, the location of the individual tasks is determined by the cost/benefits/risk analysis. This distribution of tasks at individual levels poses more complexity but it provides optimisation of cost/benefit/risk. The tailored model characteristics are as follows:

- Optimal and balanced in terms of costs, benefits, and risks

- Suitable for all project sizes
- Requires experts and maturity of processes to plan and execute

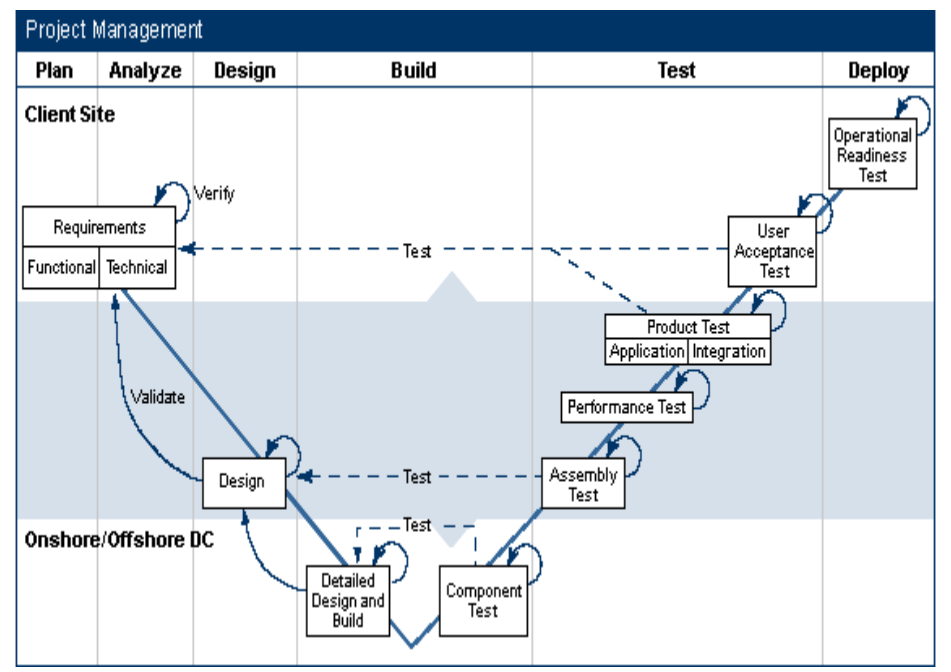

Fig. 3. Tailored Distribution Model

\section{Creating a Tailored Distribution Model}

This method requires experience and help from a delivery centre expert who is familiar with cost-risk-benefits analysis of multi-site development in offshore centres.

The method works with a two-dimensional matrix where functional areas are derived from the application requirements. The horizontal dimension corresponds to the major phases of work, such as analysis, design, component test, etc. The vertical dimension corresponds to the functional areas within the application, such as IPO, Billing, and Account Management.

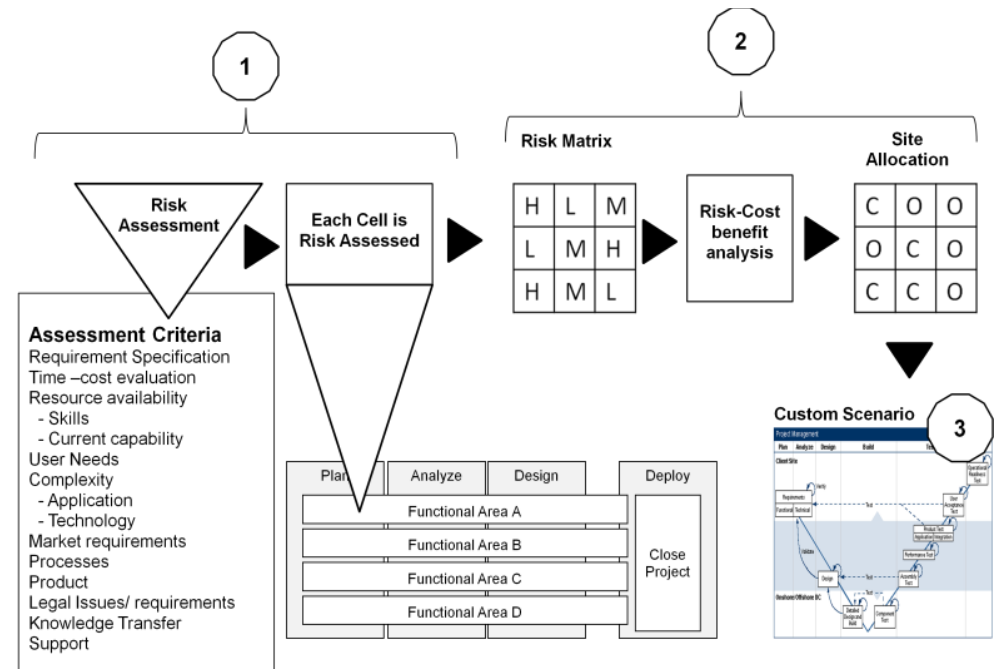

Fig. 4. Creating a Tailored Distribution Model

There are three major steps in the Tailored model:

- Assess individual criteria for each matrix, and determine the aggregate risk for a given stage/phase of work for a given functional area. The resulting 
aggregate value of High, Medium, or Low indicates the risk for executing a given stage of work for a given functional area offshore.

- Apply cost-risk-benefit analysis to each matrix cell to determine whether to execute a given stage at the onshore or the offshore centre. Consider factors such as skill availability, cost, potential knowledge transfer, etc. The result of this step is a site assignment matrix, with each cell containing a designation " $\mathrm{C}$ " Customer site, "N" Near-shore/onshore centre, or "O" offshore centre.

- The resulting matrix can be used to plan the work/ tasks.

Although the process seems simple and straightforward, it will require experts and maturity to conduct cost-risk-benefits analysis.

\section{Multi-Centre Model}

In this model, the work is distributed across at least three different sites: the customer site, the onshore/near-shore centre site, and the offshore site. The requirements gathering and analysis and the user acceptance testing are completed at the customer site. The rest of the work is shared between the onshore/near-shore and the offshore centres.

This model is able to provide the benefits of the both the DC-centric and customer-centric models. Greater cost-savings are achieved by using the offshore centre and the risk is reduced because the customer team works closely with onshore/near-shore centre.

The use of this model is on the rise, and it will be a predominant approach in the future, particularly for packagedbased development. Multi-centre model characteristics include the following:

- Combines benefits of the other two models

- Model of choice for packaged-based development

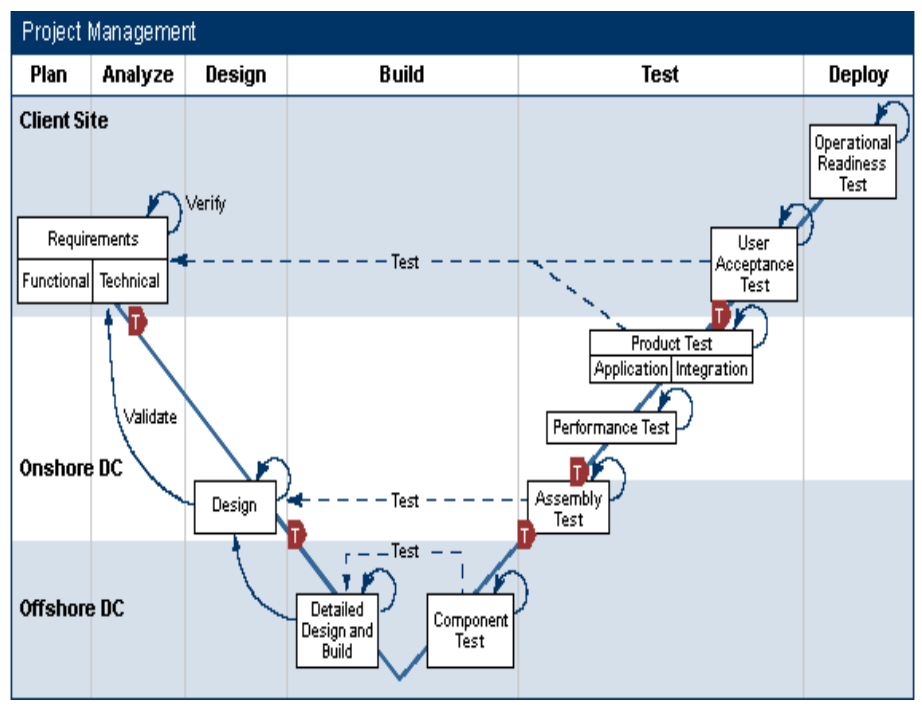

Fig. 5. Multi-centre Distribution Model
- This model is most suitable for medium and large-scale projects, as it typically involves significant start-up costs (training, infrastructure, and knowledge transfer). However, this model can work for smaller projects if they can use an existing facility or run from the same delivery/development centre.

- This model requires experts and maturity of team. Typically, the customer site team drives the business requirements while the onshore/near-shore centre drives the technical delivery work. The onshore centre also acts as a hub between the customer and the offshore sites.

- This model may not be fully suitable for projects with well established application and technology architectures because they do not require the onshore/ near-shore centre to act as a liaison between the customer site and the offshore centre. In such a case, DC-Centric model may be more suitable.

- If projects are based on a new architecture, consider a different distribution model. The complexities of dealing with three different sites are magnified by the complexities associated with managing the new architecture development.

- This model is particularly well suited for packaged software delivery:

- The model will work well with moving defined work offshore and keeping more difficult and less defined work onshore/ near-shore.

- Working through an onshore/ near-shore centre also helps overcome language barriers, time zone differences, etc.,

\section{Benefits}

- Cost savings. This model's scalability can help achieve greater savings for projects with a large build component, while shielding the customer site team from the exposure to the complexities of dealing with remote delivery centres. By using the delivery/development centre to complete more tasks, additional savings can be achieved.

- Lower risk. The risk is lowered as the near-shore/ onshore centre manages the tasks that require higher levels of communication with the customer site team (e.g., UI design, functional design etc.). This mitigates the risk of communication gap and delays.

- Higher quality. The near-shore/ onshore centre ensures the errors are corrected before the customer site receives the build components. The centre does not necessarily inspect the quality, but it will be able to facilitate the transition smoothly.

\section{Drawbacks}

- Since it involves significant start-up costs. It also requires an experienced team for execution, this model is suitable only for medium and large projects. 


\section{Distribution APPROACH Versus Maturity/ EXPERIENCE}

The diagram below depicts the relationship between the ability to execute higher complexity distribution approaches and the organizational maturity. The organizational maturity combines two notions:

- Delivery centre maturity. This may be referred as CMMI level rating, Six Sigma, ISO certification etc. attained by the delivery/development centre.

- Customer site team maturity. This is the customer site team's experience with multi-site project execution. This is often reflected in the number (percentage) of the management and development people who previously worked on a multi-site project, involving a delivery/development centre.

The graph of distribution approach vs. experience/maturity follows the S-curve, with use shifting from customer-centric scenario to DC-centric scenario.

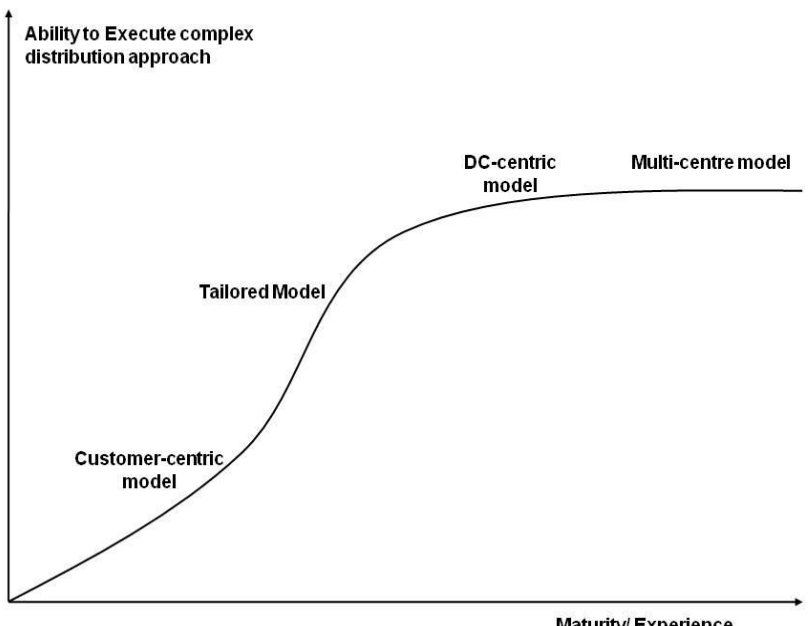

Fig. 6. Distribution Approach vs. Maturity/ Experience

The implications and considerations for the amount of experience working with a distribution approach include the following:

- The customer teams new to the multi-site may want to start with the customer-centric model.

- The customer team's maturity can be influenced by acquiring people experienced with multi-site development from a delivery centre for the team. Start with the DC-centric model if you have the right people.

- The primary considerations for selecting a specific model are listed in the table. There are situations to execute the customer-centric model long-term, regardless of experience or delivery centre maturity.

- Longer-term engagements must consider the potential for starting with a more basic approach (i.e., the customer-centric model) and incrementally migrating additional activities offshore over time. The desired end-state is achievable only over a period of time.

- Consider if there is potential for a long-term outsourcing arrangement at an offshore centre at the end of the delivery (i.e., a Design, Build, Execute arrangement). In such a case, the DC-centric model provides an additional advantage because there is no need for knowledge transfer to the customer personnel.

\section{Model ReFINEMENT}

The basic models are rarely applied on projects in their pure form. Instead, the engagement planner and managers usually refine the models based on specific aspects associated with their situations. The refinement process involves determining the best location for a given task.

For example, in the customer-centric model, the assembly or product tests can move from the customer site to the offshore centre site. Moving the assembly test to the offshore centre may be beneficial. Keeping all or a portion of the assembly test will result in removing more errors from the coded work units before they are transferred to the onshore centre or customer site.

Apply this fine-tuning process to all development tasks that lie on the border between the sites (e.g., application design). When considering moving a development task from its designated location in the model, consider risk mitigation strategies to address negative impacts of the move.

Apply the appropriate risk assessment criteria when deciding alternative locations for a given task. In general, the lower the aggregate risk results from looking across multiple risk factors, the more appropriate a given task is for execution at an offshore centre.

\section{Delivery Centre Organisation Structure}

This work further explores the management structure, arrangement/contract, and staffing/organization required for completing the project successfully. The management and organisation structure has to be selected dependent on the distributed work model for successful and efficient development and delivery of the solution/ project.

There are two key aspects of the relationship between the customer and the delivery centre teams that set apart different Delivery Centre (DC) organisation approach:

- Extent of integration between the teams, i.e., the extent to which the DC personnel are engaged/used in the project's organization and the communication requirements between the customer site and the DC personnel.

- How much and which of the DC's methodology, processes, knowledge, tools, and technical facilities are used by the project?

The above two aspects influence the organisation structure of teams at customer and offshore centre sites:

- Communication: who is in control and communication and command lines 
- Contractual/ Service Level Arrangements: what is subcontracted and the arrangement details

- Recruitment/process: project staffing, process to follow

There are four different organisation structures which have been applied successfully in different areas. These approaches may not be applied in isolation as some practices are shared across and the boundaries are not rigid for successful completion of projects.

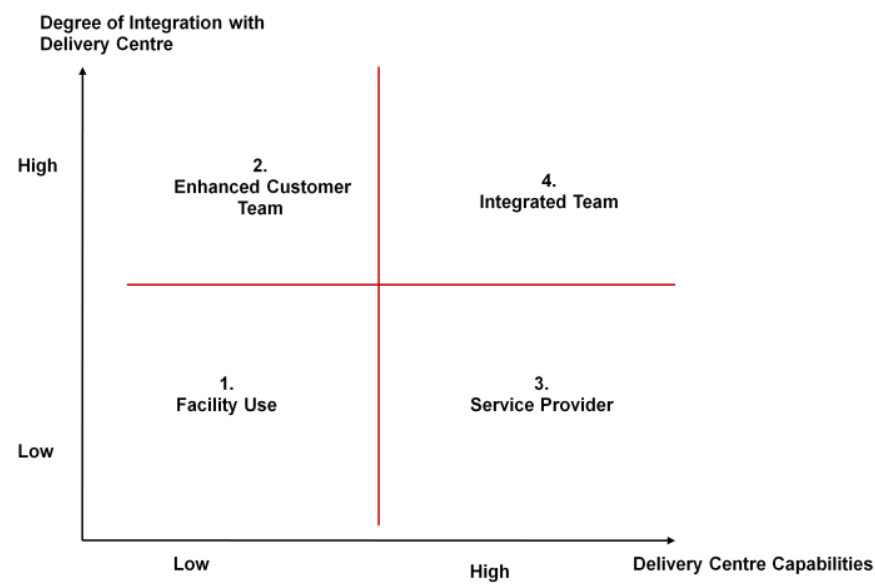

Fig. 7. Organisation structures

\section{FACILITY USE}

With this structure in place, the main aim of the customer is to get the office space from a DC on rent or lease along with the basic facilities such as desks, telephones, computers, shared file services, and connectivity to the customer site. This type of arrangement is more useful in the following circumstances:

- Projects which need to ramp-up quickly, which may be due to the following situations:

- A project having short time to market and the customer does not have time for building infrastructure or recruit staff quickly.

- Customers who do not have enough IT development space currently available in-house.

- Small projects which cannot afford higher cost of initial set-up in terms of both time and expense.

This organisation method has the following characteristics:

- Set up is easier and quick

- Influenced by the availability of infrastructure at the $\mathrm{DC}$

- Capabilities of DCs are less used

- Little communication/ integration between DCs and customer

- This is not suitable when the distances between customer and offshore centre is large

\section{Enhanced Customer Team}

This organisation method is used when the customer wants to enhance its capabilities by using the offshore resources in order to reduce the skills gap.

This organisation method has the following characteristics:

- Set up is easier and quick

- This is not suitable when the distances between customer and offshore centre is large (e.g., US with Philipines etc.)

- Capabilities of DCs are less used

- Higher level of communication/ integration between customer and DC

- Projects that will need a substantial number of skilled personnel at customer site and can be hired from DCs.

- The facilities and tools are not available at DCs.

\section{SER VICE PROVIDER}

This organisation structure is can be defined as two teams, the customer site team and the DC team, working together in a highly collaborative manner. The work is subcontracted to the DCs with set of service level agreements and is managed with an established communication process. This type of arrangement is more useful in the following circumstances:

- A task is subcontracted to the DC, and the communication between the customer and DC is managed through a set of well-defined entry/ exit criterion.

- Generally projects/ customer will adopt fixed-fee costing method for this kind of structure.

- There is more freedom to DCs to allocate and manage the resources.

- The communication process will change as per the complexity of the project.

- This method requires clear defining of the accountability and delivery parameters.

- Demand process should be clearly defined in order to use the resources in an optimised manner.

- The customer will have relatively low start-up cost of contracting with the DC team as the DCs are using already existing methodology, training, and infrastructure.

\section{Typical Use}

- Projects that want to maximize the leverage of the DC capabilities and can work within the constraints of proven offerings, a known environment, and stable architectures. For example, an ERP project based on a well-understood offering (e.g., Oracle) with a stable platform, where a set of modules needs to be coded.

- Projects that anticipate their needs may expand rapidly in the future and need a choice of DCs that can 
accommodate their requirements. For example, consider an SAP engagement in which demand rapidly surged, and it had contracts with three DCs to satisfy its capacity needs.

This organisation method has the following characteristics:

- Works well on projects with established application/technical architecture and with wellestablished and documented standards for specifying design deliverables (commodity market)

- Works well with offshore DCs

- Works well with established, mature offerings

- Works well in a fixed-fee arrangement to reduce risk of the customer site team

- Relatively low start-up costs

- Light-to-medium interaction between the customer site and DC teams

- High in leveraging the DC capabilities as the DC optimizes the use of its team and other resources

- To mitigate risks, mixing customer site and DC personnel is necessary and site liaisons could be a good option.

\section{INTEGRATED TEAM APPROACH}

The project structure is similar to that of a general commitment, except that the project team is distributed among multiple sites. The project achieves significant cost savings by:

- Utilising the DC procedures, processes, tools, and infrastructure.

- Using the DC skills and resources by filling key technical and managerial roles with the DC personnel, and by integrating a critical mass of the DC personnel.

- Setting up accountability, which is less of an issue in this approach since the project is managed as one integrated team.

\section{Typical Use}

The project may have customer-facing or functional skills, but:

- It needs the DC for technical delivery capacity/expertise, e.g., the customer site team sold the work, but needs to assemble a team quickly to deliver the technical piece.

- The project relies on the DC to provide a significant portion or all of the technical delivery methodology, approach, estimating, etc.

- The project relies on the DC to fill some management and/or team lead spots.

- The project team in the DC operates as a virtual extension of the customer site team, with a fully mixed and integrated team of the customer team and the DC personnel.

\section{Characteristics}

- The DC team tends to drive many of the technical and project management approaches.

- This approach tends to have higher set-up costs.

- This approach supports projects that are in-flight, i.e., projects that started as traditional single-site projects and then become a multi-site project working with a DC. This is because this teaming approach accommodates knowledge transfer, which is part of the transition to multi-site process.

- It has the highest degree of integration between the customer and DC personnel.

- It achieves the highest leverage of the DC capabilities. It overcomes the Service Provider approach limitation by working well for projects that are based on new and existing application/technical architectures.

\section{Choosing A TeAming Approach}

Choosing the teaming approach involves assessing engagement requirements and examining a variety of factors. Some of these factors are listed below:

TABLE I. TEAMING APPROACH

\begin{tabular}{|c|c|c|c|c|c|}
\hline $\begin{array}{l}\text { Issue/Facto } \\
\text { r }\end{array}$ & $\begin{array}{l}\text { Facility } \\
\text { Use }\end{array}$ & $\begin{array}{l}\text { Augmnt. } \\
\text { Customer } \\
\text { Team }\end{array}$ & $\begin{array}{l}\text { Service } \\
\text { Provider }\end{array}$ & $\begin{array}{l}\text { Integrat. } \\
\text { Team }\end{array}$ & Comment \\
\hline $\begin{array}{l}\text { Quick/ fast } \\
\text { Scalability }\end{array}$ & Suitable & Suitable & $\begin{array}{l}\text { Depends } \\
\text { on } \\
\text { availabilit } \\
\text { y }\end{array}$ & $\begin{array}{l}\text { Not } \\
\text { suitable }\end{array}$ & $\begin{array}{l}\text { The Integrated } \\
\text { Team approach } \\
\text { does not work for } \\
\text { fast scalability } \\
\text { because of the } \\
\text { set-up } \\
\text { costs/effort. }\end{array}$ \\
\hline $\begin{array}{l}\text { New } \\
\text { Architecture }\end{array}$ & $\begin{array}{l}\text { Question } \\
\text { able }\end{array}$ & Suitable & $\begin{array}{l}\text { Not } \\
\text { suitable }\end{array}$ & Suitable & $\begin{array}{l}\text { Since a new } \\
\text { architecture } \\
\text { requires a high } \\
\text { degree of } \\
\text { interaction with } \\
\text { the customer and } \\
\text { the customer } \\
\text { team, hence } \\
\text { Service Provider } \\
\text { type of interaction } \\
\text { is not suitable. }\end{array}$ \\
\hline $\begin{array}{l}\text { Work-in- } \\
\text { progress } \\
\text { projects }\end{array}$ & Suitable & Suitable & $\begin{array}{l}\text { Questiona } \\
\text { ble }\end{array}$ & Suitable & $\begin{array}{l}\text { Work-in-progress } \\
\text { projects require } \\
\text { knowledge } \\
\text { transfer, so } \\
\text { Service Provider } \\
\text { approach is not } \\
\text { appropriate. }\end{array}$ \\
\hline
\end{tabular}




\begin{tabular}{|c|c|c|c|c|c|}
\hline $\begin{array}{l}\text { Issue/Facto } \\
\mathbf{r}\end{array}$ & $\begin{array}{l}\text { Facility } \\
\text { Use }\end{array}$ & $\begin{array}{l}\text { Augmnt. } \\
\text { Customer } \\
\text { Team }\end{array}$ & $\begin{array}{l}\text { Service } \\
\text { Provider }\end{array}$ & $\begin{array}{l}\text { Integrat. } \\
\text { Team }\end{array}$ & Comment \\
\hline $\begin{array}{l}\text { Short time- } \\
\text { to-market }\end{array}$ & Suitable & Suitable & Suitable & Suitable & $\begin{array}{l}\text { If the project } \\
\text { length is less e.g. } \\
3 \text { months or so, } \\
\text { and an offshore } \\
\text { centre is to be } \\
\text { involved, then } \\
\text { Integrated Team } \\
\text { approach may not } \\
\text { be suitable. }\end{array}$ \\
\hline $\begin{array}{l}\text { More } \\
\text { knowledge } \\
\text { transfer }\end{array}$ & N/A & Suitable & $\begin{array}{l}\text { Not } \\
\text { Suitable }\end{array}$ & Suitable & $\begin{array}{l}\text { If higher } \\
\text { knowledge } \\
\text { transfer is } \\
\text { required, then } \\
\text { service provider } \\
\text { approach is not } \\
\text { suitable. }\end{array}$ \\
\hline
\end{tabular}

\section{Processes and Procedures for Onshore/ OFFSHORE/ NEAR-SHORE WORK}

The distributed onshore/offshore/ near-shore work arrangements require a number of steps to be completed. These are very much different from the traditional project management at one site. Therefore, organisations need to create a set of processes, procedures, tools, and techniques so that the distributed work can be managed effectively and efficiently. This helps organisations to manage and share the work across locations with a standard set of rules and processes. This ensures consistency and reusability of the resources/ documents and deliverables across projects.

Organisations can also get certifications like CMMI/ SixSigma or any other standard methodology for their processes, procedures, tools, and techniques. This is highly important to build confidence of customers in the delivery of projects on time and on budget.

\section{Managing Transitions Across Phases/ Multiple SITES}

Transition of project across multiple sites requires different set of processes, procedures, tools and techniques. The traditional transition processes of moving from analysis to design to build stages etc. may not be fully applicable. Therefore, organisation needs to define its new set of processes to manage the work/ project effectively.

Organisation must consider the following issues to prepare the plan and manage the work:

- What is the best possible and optimum way of transfer of knowledge from one site to another

- Monitoring and Controlling process

- Dry run of the project

- Managing risks
- Approval of the transition process by the stakeholders

- Prepare checklists for various stages of the project

- Prepare contingency plan

- Skills-gap analysis for resources

Keeping in mind the above issues, the following are some of the effective techniques to manage the transfer of the project to the development centre.

- Process for Knowledge transfer: Organisation must use a good process to transfer the knowledge from one site to another and this has to be measured against baselines to make it efficient.

- Managing with Checklists: Checklists are created for various modules, deliverables, documents, hardware, software, databases, resources and skills. These are very effective in controlling and seeing the progress of the project.

- Dry run/ pilot run: Project is given a dry run for a few set of data to see that the overall objectives are met and project is behaving as per the expectations before the final release and go-live.

- Reduce communication gap: Do regular secure information sharing with stakeholders. During transition, see the possibility of having key users can work at development centre.

\section{CONFIGURATION Management (CM)}

In the multi-site environment, the most affected area is configuration control. Organisation must create set of processes, procedures, tools and techniques to manage the integrity of the project across sites and ensure various stages are completed as per the plan.

The repository for the configuration management must be able to provide service to all the sites with ease and flexibility and also adhering to the various security concerns.

Organisation has to consider following questions:

- Has the CM plan/approach been defined?

- Has the change process been defined and approved?

- Has the CM effort been estimated and budgeted?

- Is there involvement of resources from the delivery centre?

- Have you identified roles for CM support activities?

- Have you signed an agreement/SLA with the delivery centre for CM support?

- Has ownership for all files/objects been assigned?

- Has long-term ownership of the CM repository been resolved?

- Have contingency and roll-back plans been established in case the repositories get out of synch? 
- Have plans for CM audits been addressed in the CM plan, and are they covered by the CM budget?

- Are there plans to test the CM repository from all remote locations to ensure that accessibility and performance requirements are met?

- Approval of CM plan by stakeholders.

- Connectivity issues: The connection speed, bandwidth, and cost influence where the repository can be located and which CM tools to be used. Various options are VPN, Leased line, Company-WAN, etc.

- Where would the repository be located?

Three approaches for organizing a CM repository are identified as best practices: centralized, independent repositories, and multi-site with replication. These approaches differ from each other in terms of performance, flexibility, and cost.

Centralised Repository: This offers high flexibility, easy set-up and operate, easier regulation and compliance due to single site but its performance is dependent on the connectivity.

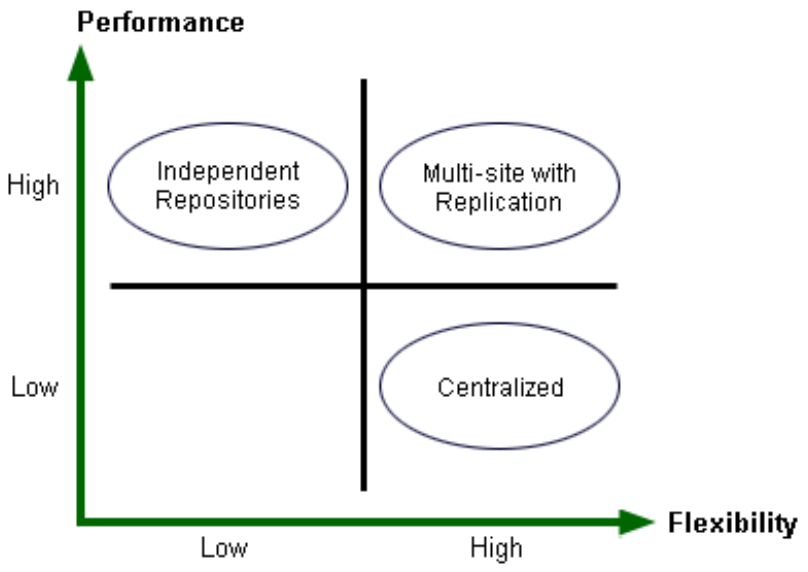

Fig. 8. Potential Repository Locations

Independent repositories: Low Flexibility, medium set-up complexity, high performance as individual site has its own $\mathrm{CM}$ tools, files are synchronised manually.

Multi-site with replication: High performance, Higher flexibility, but with higher set-up costs, requiring high-speed and bandwidth connection

- What are the various CM Tools?

- Availability

- Number of sites

- Project Size and complexity

\section{ESTIMATION PROCESS}

Estimation process is difficult for the distributed work, as the number of parameters is more due to the involvement of multi sites. Significant effort has to be put into arriving at the estimate of time and cost for completion of the project. Development centre must be involved in the estimation process in order to minimise the risk. Organisation must take into account the followings issues:

- Has the estimation for time, effort and cost been done and approved by appropriate stakeholders?

- Have you created service level agreement and approved by stakeholders?

- Have you planned for time and budget for training of offshore resources?

- What is the plan for knowledge transfer and budget as well as time frame for the same?

- Have the estimates considered risk factors such as lack of communication, cultural issues, resource availability, and technology differences, etc., which are common in multi-site development? What kind of buffer is available?

- What is the contingency plan?

- Are all key areas covered in the estimates: analysis, design, build, test, etc.?

- Is the cost for monitoring and controlling also be estimated?

- Have you involved all stakeholders, technical and functional, to assist the estimating?

- Have you allocated budgets across organizations/locations and assigned responsibilities for deliverables?

- What are the expenses for travel, communication between sites, etc.?

- For costing the project, have you involved the delivery centre experts in providing rate, tax, multi-year inflation adjustments, etc. into the cost calculations?

- Have you considered any pre-existing master services agreement conditions that you may already have with the customer in terms of pricing this new deal?

- Have you accounted for currency and inflation risks (expenses will be through local currency)?

\section{INTERCULTURAL GUIDELINES FOR DistRIBUTED WORK}

It is crucial for today's business personnel to understand the impact of cross cultural differences on business, trade and internal company organisation. The success or failure of a company, venture, merger or acquisition is essentially in the hands of people. If these people are not cross culturally aware then misunderstandings, offence and a breakdown in communication can occur.

The need for greater cross cultural awareness is heightened in our global economies. Cross cultural differences in matters such as language, etiquette, non-verbal communication, norms and values can, do and will lead to cross cultural blunders. 
U.S. and British negotiators found themselves at a standstill when the American company proposed that they "table" particular key points. In the U.S. "Tabling a motion" means to not discuss it, while the same phrase in Great Britain means to "bring it to the table for discussion."

Cultural awareness is crucial for any development project involving multiple countries or workforces. Differences in culture can affect team communication and influence team processes. This has always been an aspect of project work, and will become increasingly prevalent as more and more projects use multiple development sites and local and global workforces. It is important to value the diversity of people and practices across the world. The company's underlying code of ethics and positive support of people through company-wide programs are key pillars of running any successful engagement. Organisations should consider the following issues for effective communications across different countries and cultures:

- Increasing cultural awareness

- Identifying a communication strategy to overcome language barriers

- Encouraging team work

- Providing opportunities for face-to-face interactions

- Using effective virtual teaming tools

- Addressing country-specific business hours and holidays

- Groups vs. individual orientation

- Hierarchy and status

- Risk taking ability

- Communication Style - Direct/ Indirect

- Task vs. relationship

- Short term vs. long term

- Use of implicit and explicit messages

- Tolerance for ambiguity

- Responses to problems

- Use of silence for showing respect vs. asking questions up-front

- The desire to please others vs. the desire to identify issues.

- The desire to preserve other people's dignity and selfrespect.

- Different emphasis on time.

- The desire for perfection.

- A strong social network.

- A strong work ethic.

\section{COMmOn EXPECTATIONS}

Language skills are a key part of working across geographies, and English is often the most common business language used. Accents may initially cause a few issues.

If there is a language barrier, identify a communication strategy to overcome it.

- Identify leaders with good language skills as key contacts and include them on all project status calls.

- Some people have good language skills, but may not be as confident as others. Some, who may feel less comfortable in the multicultural work environment, are likely to be more timid in discussions. During meetings, explicitly invite them to speak their thoughts and opinions.

In general, multi-site projects use extensive written communications to minimize misunderstanding verbal messages. Instant messaging tools can be an effective substitute for telephone conversations in circumstances like this.

Some cultures are not accustomed to writing in English at the volume that projects require, so use a combination of written and verbal communication that makes sense to the overall project team.

Organisation should consider the following questions for improving cross cultural awareness:

- Be aware of your own culture. What is your communication, decision making, and issue management style?

- Did you learn about the culture of global colleagues?

- What are the plans to raise cultural awareness across the project team?

- Are you aware of the potential cultural differences that affect your project's communication, decision making, and issue management?

- How will you respond to these cultural differences as a project and as an individual?

- What plans do you have to promote collaboration and communication?

- Have you communicated these plans to both the customer (local) site and the global teams?

- Have you trained both the customer site and global teams to use the virtual teaming tools effectively?

- Have you met the teams from the different geographies?

- How will you measure that your multi-country and/or multi-workforce project team is communicating effectively? 


\section{ISSUE/ Problem MANAGEMENT}

Issue/problem management involves the process for identification, analysis, resolution, reporting, and escalation of the project's issues and problems. There has to be clear documentation of how and with which parameters issues are prioritized, assigned, communicated, viewed, escalated, and resolved.

With multiple sites and lesser face to face communication, resolving issues and problems is more difficult. Therefore, teams at different sites will have to rely on a common process and/or an automated tool to track, share, and resolve issues/problems in a timely manner.

Organisation should consider the following parameters for managing the issues effectively and efficiently:

- Plan issue/problem management.

○ Define the issue/problem management objectives and goals.

○ Define the issue/problem management process. Include escalation procedures.

- Identify issue/problem management roles.

- Identify issue/problem management tools.

- Finalize issue/problem management plan. Ensure all sites understand and agree to the plan.

- Execute issue/problem management processes.

○ Identify issues/problems.

○ Track issues/problems.

○ Assess issues/problems.

- Develop issue/problem resolution.

- Monitor and communicate on issues/problems.

- Report metrics.

Organisation should consider the following questions:

- Is an issue and problem management process established?

- Have you selected issue/problem management tool(s)? What is the installation/roll-out plan for the tool(s)?

- Are issue/problem management roles defined and assigned?

- Are issue/problem documentation standards defined?

- Has an escalation process been established?

- Have you developed a plan for communicating issues/problems to team members and the customer?

- Does training exist for those who use the issue/problem management tool(s) and processes?

- Were metrics created to measure the effectiveness of the issue/problem management process?

- Have you done a causal analysis of the issues at defined milestones?

\section{RESOURCE MANAGEMENT AND ORGANISATION DESIGN}

Understanding Organisation design is very important so that various challenges of current capability assessment, enterprise environmental factors like work, culture, management style, etc. can be addressed for organising a distributed project team, define project roles, and manage the resources. This will help stakeholders estimate the work effort, and plan for the work, and efficient use of resources and communicate clearly the roles and responsibilities. In order to manage the distributed effectively and efficiently, stakeholders form all areas must be involved in planning, and build team behaviour and not Offshore vs. onshore team /client team.

\section{Approach}

Organisation structure and design could be as follows:

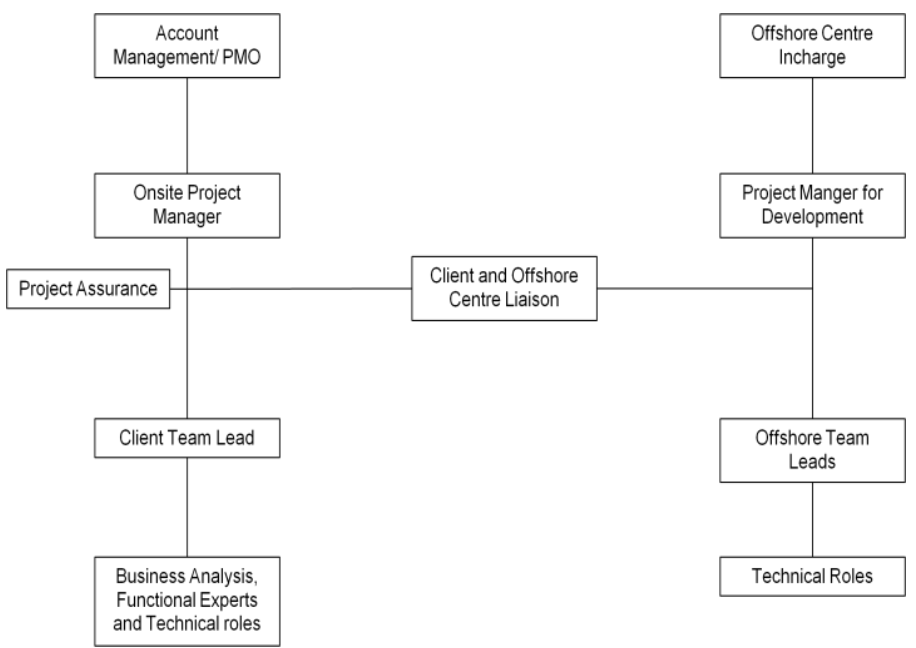

Fig. 9. Standard Organization Structure

- Account Management/ Program Management Office takes care of the all the projects being developed with customer. This is required to care of business requirements and customer stakeholder expectation management.

- Offshore Centre In-charge is responsible for all the projects running at the centre.

- Onsite Project manager takes care of the full project, managing schedules, budgets, project execution, monitoring and controlling. Project Manager communicates all the project progress to all the stakeholders directly and through Client and Offshore Centre Liaison. Project Assurance manages and communicates the status of the project to all stakeholders and monitors the project risk and escalates the risk/ issues as required.

- Offshore Centre manager for Development is responsible for managing the work at offshore centre and also provide status report to the onsite project manager. 
- Client and Offshore Centre Liaison is to improve the communication between the onsite and offshore centre and provide information to all stakeholders to minimise the risk.

- Team leads at individual sites manages their respective teams for performing various business, functional and technical roles to complete the project as per the plan and manage the resources efficiently and effectively.

In addition to making organization and staffing of the project more complex, multiple sites also makes managing the resources more complicated than with traditional, one-site projects.

Project manager and stakeholders must take care of the following:

- Leverage delivery centre resources as much as possible when staffing projects to take advantage of the deep application and technical skills and cost savings. Engage delivery centres early to secure resources.

- Subject matter experts (SMEs) are needed from the DC to help define and refine the estimates and work plans.

- Each centre is different from other in the staffing model, resource management, processes and procedures. Work closely with delivery centre liaisons so that right skills people can be identified quickly. This will help you avoid delays in obtaining resources. Understand the delivery centre's demand management processes so that necessary lead times can be accounted for in the project schedule.

- The cost structure associated with delivery centre resources varies.

- Liaisons can help you to find resources and guide through the complexities of identifying and procuring offshore resources in a manner that complies with company and national labour policies - for example, visa, wages and expenses, and tax considerations.

- UK work permit process is different from the USA and also the time required is different. Visa lead times vary by country of application (India vs. China) and by cities within a country (Bangalore vs. Mumbai). Visa lead times also vary by visa type $(\mathrm{H}, \mathrm{L}$, etc). The leadtimes vary over time as per new government legislations from time to time.

- Discuss about the management style: dual management or not; long-term planning for resources, fully utilising the resources from offshore centre, etc.

- Is the project to be released in multiple stages? What are the plans for multiple releases?

- How will you take care of attrition of skilled resources?

- Roles and responsibilities are clearly defined for each team member including owner, reviewer, and approver of the various deliverables and milestones in each stage. Consider bringing offshore resources onshore and vice versa for better understanding and also transition of work/ tasks.

- To break cultural barriers, involve people from different teams and form virtual sub groups.

- Treat each member equally even though their parent organisation policies may be different e.g. vacation and holidays, working hours, overtime, and flexible work hour policies.

The following points may be considered for an effective organisation design and resource management in distributed environment:

- Have all stakeholders (customer site, delivery centres, users, $3^{\text {rd }}$ party vendors, etc.) been considered, when defining the organization design and resource needs?

- Consider involving client for organisation design and resourcing needs.

- Early notification to the delivery centre resourcing personnel during the selling process to tell them that a deal is under progress in which they may be involved?

- Involvement of subject matter experts from all sides for proposal, estimating, and planning of the project.

- Has an organization design and hierarchical structure been defined and approved by all the stakeholders?

- Is there roles and responsibility document and matrix? Does everyone agrees and approves it?

- How will the third parties be integrated? What are their roles and responsibilities and deliverables?

- What are the communication processes and requirements for the current project?

- Is the offshore centre being used for only for application and technical skills? What will be the cost savings?

- Does the project need contract staff for filling in the skills gap?

- Does the project management overlaps with other projects?

- From the project requirements and scope, pan effectively and efficiently for the future demand of resources.

- Consider the appraisal process and career progression path of the offshore resources. This should be managed as per the needs of the centre.

\section{CASE STUDY}

The purpose of the group ERP Consolidation project (GERP) is to implement one SAP based ERP application that will support standardised and simplified business processes for all of the group businesses in organisation-Z. The project planning and management was done as per the PMBOK process and knowledge management areas. 
This project is classified as a Business Initiative. Benefits will arise from the lower cost of ownership of a single consolidated ERP system for the Service Companies and the reduced cost of support through offshoring a significant part of the new support organization required to support the consolidated application. Additionally, business benefits will arise through the consolidation of back office functions enabled through use of simplified, standardised business processes and systems.

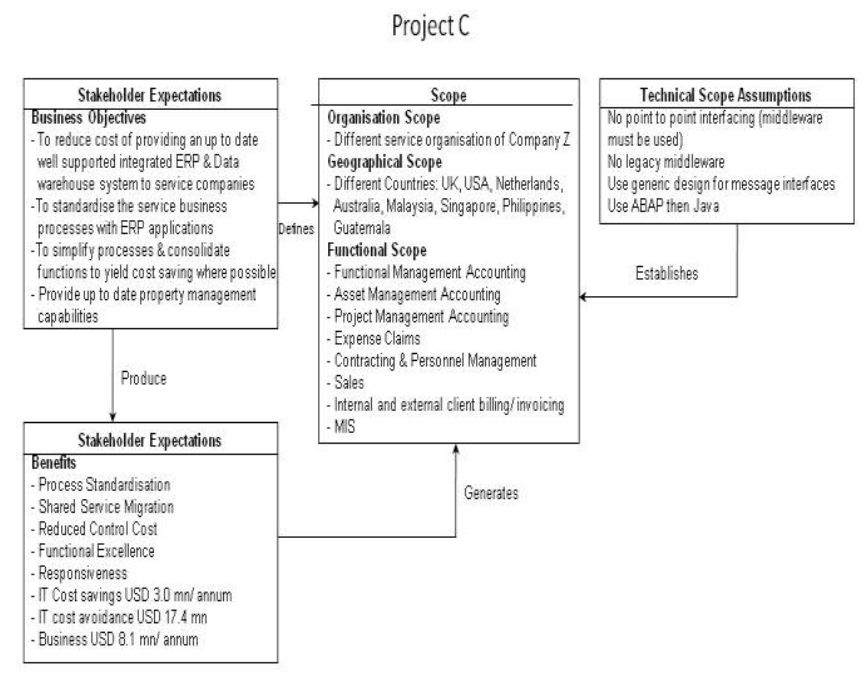

Fig. 10. Project ' $C$ '

The main business objectives of this project are:

- To reduce the cost of providing an up to date, well supported integrated ERP and data warehousing system to the Companies.

- To standardize the business processes with ERP applications.

- To simplify Services business processes and to consolidate functions where possible to yield cost savings in operating those functions.

- Provide up-to-date Property Management capabilities where organisation's Real Estate Services can consolidate property information and can standardise business processes associated the administration of organisation's property.

The project objectives are in line with the CMD, CFO and other who endorse Group ERP Strategy based on SAP software. The project objectives are also in line with IT to reduce IT application support costs across the Group through rationalization of IT applications and offshoring of application support. The project objectives are also consistent with the recommendations to use consistent processes across the group and supported by one common system. Additionally, the project objectives are also consistent with the finance strategy to standardize and simplify financial processes, provide increased transparency of financial information and a consistent controls framework.

\section{IT OPERATIONAL COST / BenEFIT}

To estimate future IT operational cost, the Operational Cost information for the individual Service applications was collected and decomposed into three areas; ERP Cost, Data Warehouse Cost, and Other ERP Related Costs. Each of these cost components, was further broken down by: Hardware, Software License Fees, Application Support and Run \& Maintain Enhancements Costs.

From this base information, collected from the focal points, forecasts were made using knowledgeable resources, accepted estimating models and assumptions based upon best information.

An estimated \$3.1 million in benefits may be obtained in IT operational cost by consolidating the Services businesses on to one ERP application.

The following are the guidelines followed to determine the portion of the project costs that should be considered capital and expense.

- Program \& Management costs

- Strategic investments required to deliver the system

○ $60 \%$ capital and $40 \%$ expense

- Implementation costs

○ Development predominant activity

- $100 \%$ capital

- Training and data conversion

- $100 \%$ expense

- Post go-live operational \& support

○ $100 \%$ expense

- Post go-live upgrades

○ $100 \%$ capital

\section{XXV.RECOVERY MECHANISM}

Ownership of the GERP project is based upon a cost recovery model where all participants share in the ownership of the intangible asset. The premises for the ownership and cost allocation is:

- Single entity captures costs associated with GERP

- Periodically (quarterly) cost are passed to the participating entities

- Capital cost are recorded as work in progress

- At go-live benefiting business entity reimburses and records intangible asset and amortize asset over 5 years

- Recommend payment based on named number of users and any unique customization charged to requesting entity

- Payment "trued-up" upon completion of project 


\section{STRATEGIC / INTANGIBLE BENEFITS}

Additional strategic and intangible benefits associated with the consolidation of the Services ERP and data warehouse applications have been identified (but these are difficult to quantify). Benefits include:

- Faster and less costly implementation of new strategic initiatives

- Platform available for any future new Business Service or Functions inclusion of which should lower costs for all participants

- Easier sharing of best practices

- Facilitates off-shoring/outsourcing.

- Facilitates improved controls and compliance

- Common processes and formats for customers

- More flexible workforce

- Enhanced decision making through more readily available and higher quality Management Information

- Easier benchmarking across Business Services and Functions

- Consolidated view of services position across customers/suppliers.

\section{PRoJeCt MANAGEMENT}

The project planning and management was done as per the PMBOK process and knowledge management areas. Various documentation and deliverables were created along with milestones. The project was managed using multi-centre scenario as given below:

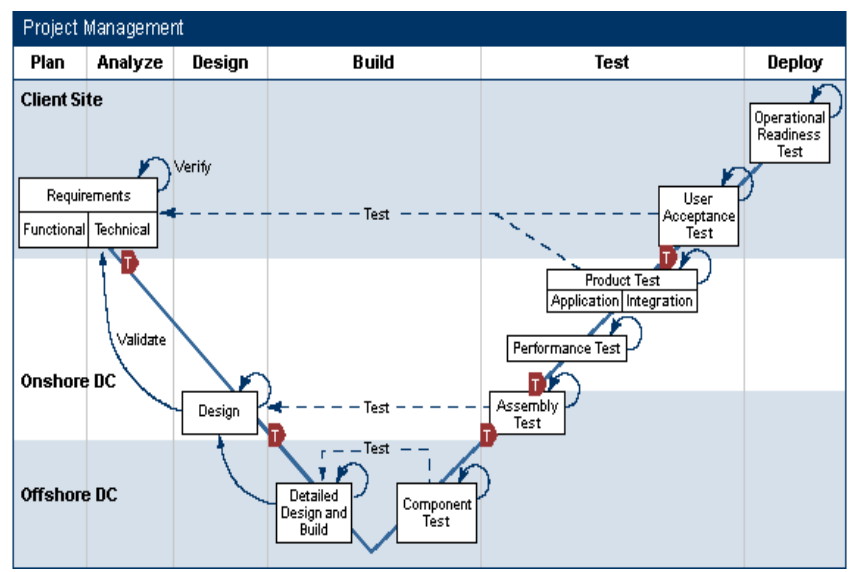

Fig. 11. Multi Centre Scenario

All the requirements were gathered at all the locations and design was validated at the onshore site and detailed design done at offshore DC along with various component tests and part of assembly tests. Solution was then implemented at the onshore sites in various countries and final testing at client locations.

This model provided the benefits of the both the DCcentric and customer-centric models. Cost-savings achieved by using the offshore centre and the risk was reduced because the customer team works closely with onshore/near-shore centre.

\section{PROJECT TIMELINE}

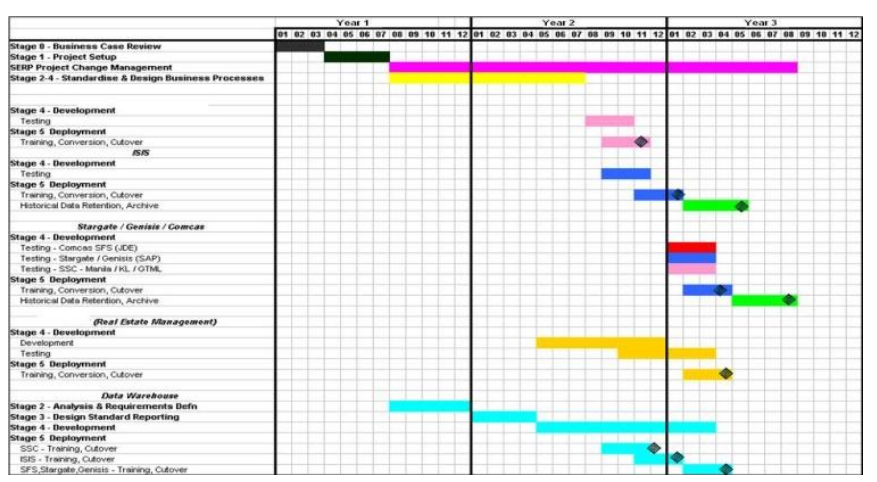

Fig. 12. Timeline

The Services ERP project will implement a rigorous risk management process, which will identify potential risks, qualify their probability of occurrence, quantify their potential cost and time impact, and define risk mitigation and avoidance strategies.

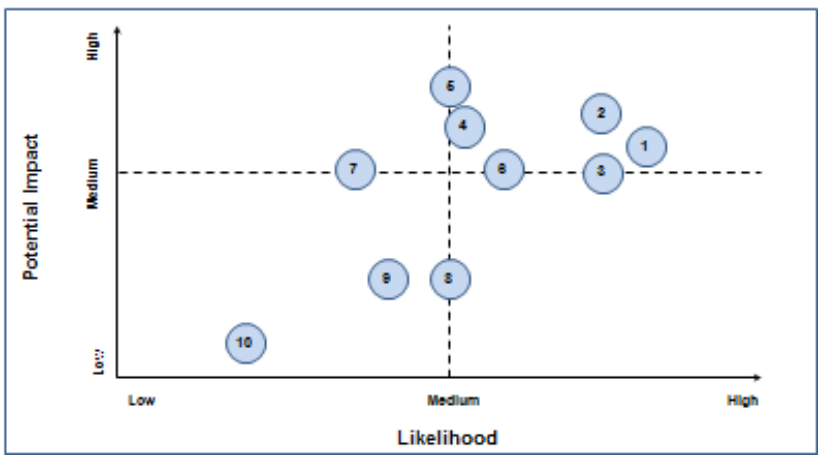

Fig. 13. Risk Prioritisation

Above diagram shows the risks are identified as 1.Internal resources, 2. Organisational Change Resistance, 3.Historical Data Retention Requirements, 4. Group Consultation/ Documentation, 5.Benefits Realization, 6. Group Business Process Requirements conflicts 7. Delay with group ERP implementation 8. Business Reorganisation 9.Project Cost overrun, 10. Higher infrastructure costs.

Risk response planning was also created and monitored and controlled by the project management office.

\section{VALUE PROPOSITION AND ECONOMICS}

Consolidation of these four different ERP systems and data warehouse systems delivered approximately $25 \%$ reduction in IT related cost, as well as potential business cost savings enabled by the consolidation of these systems and standardisation of business processes.

Summary of Savings

\begin{tabular}{|c|c|}
\hline Business & $\$ 8.1 \mathrm{~m}$ p.a. \\
\hline IT & $\$ 3.4 \mathrm{~m} \mathrm{p.a.}$ \\
\hline IT Cost Avoidance & $\$ 17.4 \mathrm{~m}$ \\
\hline
\end{tabular}


The benefits are described in more detail below.

\section{BuSINESS COST SAVINGS}

Implementing and centralising standard processes generated approximately USD $7.4 \mathrm{~m}$ p.a. of the USD $8.1 \mathrm{~m}$ cost savings. Financial closing and central master data maintenance are examples of where cost savings can be realised. This resulted in reduction of business resources to support GERP and allowed moving more operational functionality to low-cost centers. Further cost reductions were realised for a reduced number of annual system audits $(.2 \mathrm{~m}$ p.a.) and $.5 \mathrm{~m}$ in simpler implementation of future Group initiatives like SOX documentation, International Accounting Standards adoption, Global Credit Card rollout, etc.

The GERP Application is a key enabler to significant changes in the management of Services business processes and related financial information. One such potential change is the simplification and standardisation of the intra and intercompany billing process. Standard intra and inter-company process on a single ERP platform will facilitate additional efficiencies in the Shared service centers. Central HR benefited from improved intra and inter-company processes through reduced number of interfaces of payroll information from employees and reduced number of applications that require account analysis. Reduced invoice volumes, standardised customer invoices, improved data integrity and fewer resources doing internal business will result in additional efficiencies. Benefits were also achieved from consolidation of master file data maintenance and financial closing functions into a common back office.

\section{IT Cost SAVINGS}

USD $3.4 \mathrm{~m}$ annual savings in IT operating cost are estimated through reduction of ERP and data warehouse applications to one consolidated system. Reduced application support costs drive the largest savings in IT cost from approximately USD $5.3 \mathrm{~m}$ to USD $2.5 \mathrm{~m}$. This USD $2.8 \mathrm{~m}$ saving is due to the reduction in the number of FTE's required to support the application and off shoring of application support as per ICT Vision. The overall system enhancements expenditure reduced somewhat through avoidance of duplicated spend.

The savings in system enhancements is USD $0.5 \mathrm{~m}$ per annum. Real Estate Services realised approximately USD $0.3 \mathrm{~m}$ p.a. savings by replacing the $\mathrm{ABC}$ application with the Property Management functionality transferring to SAP and other functionality to other standard packages.

\section{IT Cost AvoIDANCE Benefits}

A total of approximately USD $17.4 \mathrm{~m}$ has been identified in one-time cost avoidance benefits. This is comprised of a USD $4.5 \mathrm{~m}$ required upgrade of $\mathrm{XYZ}$ in earlier to a supported SAP version. The current XYZ SAP version (x.x) is supported through a temporary arrangement with annual cost increases and will become increasingly difficult to support and adapt to business needs.
Without one standard ERP, inconsistent financial processes and controls across the Services and Functions would have remained and above benefits would not have been realised. In addition there was a continued risk of failing to achieve lower cost finance function without GERP.

\section{CONCLUSIONS}

With increasing globalisation, organizations are now using more and more distributed work environments and the management of such large distributed projects is always complex and difficult. This paper discussed various models, processes and flows for the effective and efficient management of distributed or onshore/ offshore projects. Four key models were described along with their characteristics, their advantages/ disadvantages and the best possible scenario in which each is applicable. It also focused on the teaming and organization structure approaches. Various advantages and disadvantages of each teaming approach were also discussed along with the selection criterion for project/ situation.

Earlier research focused on discussing very simple techniques/ processes and very basic organisation structure, but could not clearly define models how the work will be distributed among onshore, near shore, and offshore centres. In our research, four models and four teaming approaches are discussed, highlighting the importance and selection criterion, characteristics, and their best scenarios for use.

A case study of one of the projects using one of the models (i.e Multi Centre Scenario) has shown that major benefits could be achieved. These benefits are highlighted as business cost savings, IT cost savings, and IT Cost avoidance benefits. The project planning and management was better and the project was delivered on time with improved and enhanced project monitor and control mechanism.

All other project management knowledge and process areas of PMBOK were used effectively and efficiently. All the documents, deliverables were created as per PMBOK and milestones monitored and controlled to deliver project in various countries.

A very large number of organisations now manage projects globally and use some kind of process for managing projects in different countries. The models and teaming approaches defined here will be highly beneficial to such organisations as this paper describes a better structured flow, processes and organisation structure to manage global/ distributed projects effectively and efficiently.

\section{REFERENCES}

[1] Armstrong, D.; Cole, P., "Managing Distances And Differences In Geographically Distributed Work Groups" in P. Hinds \& S. Kiesler (ed.) Distributed work, MIT Press, 2002, pp. 167-186

[2] Salger, F.; Englert, J.; Engels, G., "Towards Specification Patterns for Global Software Development Projects - Experiences from the Industry", 7th International Conference on the Quality of Information and Communications Technology (QUATIC), Portugal, 2010 , pp 73-78

[3] Salger, F.; Sauer, S.; Engels, G.; Baumann, A., "Knowledge Transfer in Global Software Development - Leveraging Ontologies, Tools and Assessments", 5th IEEE International Conference Global Software Engineering (ICGSE), USA, 2010, pp 336-341 
[4] Narayanan, Sidharth; Mazumder, Sumonta; R., Raju, "Success of Offshore Relationships: Engineering Team Structures", International Conference on Global Software Engineering, ICGSE'06, USA, 2006, pp 73- 82

[5] Persson, J.S.; Mathiassen, L.; Boeg, J.; Madsen, T.S.; Steinson, F., "Managing Risks in Distributed Software Projects: An Integrative Framework", IEEE Transactions on Engineering Management, vol. 56, Issue: 3, 2009 ,pp 508-532

[6] Khan, H.H.; Malik, N.; Usman, M.; Ikram, N., "Impact Of Changing Communication Media On Conflict Resolution In Distributed Software Development Projects", 5th Malaysian Conference in Software Engineering (MySEC), Malaysia, 2011, pp 189-194

[7] Lane, M.T.; Agerfalk, P.J., "Experiences in Global Software Development - A Framework-Based Analysis of Distributed Product Development Projects", 4th IEEE International Conference on Global Software Engineering, ICGSE, Ireland, 2009, pp $244-248$

[8] Niinimaki, T., "Face-to-Face, Email and Instant Messaging in Distributed Agile Software Development Project", 6th IEEE International Conference on Global Software Engineering Workshop (ICGSEW), Finland, 2011, pp 78 - 84

[9] Czekster, R.M.; Fernandes, P.; Sales, A.; Webber, T., "Analytical Modeling of Software Development Teams in Globally Distributed Projects", 5th IEEE International Conference on Global Software Engineering (ICGSE), Ireland, 2010, pp 287-296

[10] Bartholomew, R., "Globally Distributed Software Development Using An Immersive Virtual Environment", IEEE International Conference on Electro/Information Technology, EIT, USA, 2008, pp 355-360

[11] Hashmi, J.; Ehsan, N.; Mirza, E.; Ishaque, A.; Akhtar, A., "Comparative Analysis Of Teams' Growth In Offshore And Onshore Software Development Projects", IEEE International Conference on Management of Innovation and Technology (ICMIT), Singapore, 2010, pp 1163-1167

[12] Hinds, P.J.; Bailey, D.E., "Out of Sight, Out of Sync: Understanding Conflict in Distributed Teams", Organization Science, 2003, vol. 14 (6), pp 615-632

[13] Swan, Bret; Belanger, France; Beth Watson-Manheim, Mary, "Theoretical Foundations for Distributed Work: Multilevel, Incentive Theories to Address Current Dilemmas", IEEE 37th Hawaii
International Conference on System Sciences, Hawaii, vol. 1/04, 2004 pp 1-10.

[14] Bailey, D. E.; Kurland, N. B., "A Review Of Telework Research: Findings, New Directions, And Lessons For The Study Of Modern Work", Journal of Organizational Behavior, vol.23, 2002, pp 383-400

[15] Pinsonneault, A.; Boisvert, M., "The Impacts of Telecommuting on Organizations and Individuals: A Review of the Literature", in "Telecommuting and Virtual Offices: Issues and Opportunities", Johnson, N.J., London: Idea Group Publishing, 2001, pp 163-185

[16] Pearlson, K.E.; Saunders, C.S., "There's No Place Like Home: Managing Telecommuting Paradoxes", Academy of Management Executive, vol. 15, 2001, pp 117-128

[17] Belanger, France; Beth Watson-Manheim, Mary; Jordan, D.H., "Aligning IS Research and Practice: A Research Agenda for Virtual Work," Information Resources Management Journal, vol. 15, 2002, pp. 48-70

[18] Igbaria, M., "The Driving Forces in the Virtual Society," Communications of the ACM, vol. 42, 1999, pp 64-70

[19] Alveson, M, "Knowledge Work and Knowledge-Intensive Firms". Oxford University Press, New York, 2004

[20] Hornett, A., "The Impact of External Factors on Virtual Teams: Comparative Cases", in Pauleen, J. (ed.), "Virtual Teams: Projects, Protocols and Processes", Idea Group Publishing, UK, 2004

[21] Turkington, D., "Remote Resourcing", The Beca Infrastructure Board, Auckland 2004

[22] Bélanger, F.; Collins, R.W., "Distributed Work Arrangements: A Research Framework", The Information Society, vol 14, 1998, pp 137152

[23] Cramton, C.D., "Attribution in Distributed Work Groups", in Hinds, P.J.; Kiesler, S. (ed.) "Distributed Work", MIT Press. London, England, 2002, pp 191-212

[24] Mohammad Jafari, M.; Ahmed, S.; Dawal, S.Z.M.; Zayandehroodi, H., "The Importance Of E-Collaboration In SMES By Project Management Approach A Review", 2nd International Congress on Engineering Education (ICEED), Malaysia, 2010, pp 100-105

[25] A Guide to the Project Management Body of Knowledge, 5th edition, PMI, USA, 2013 